\title{
Architectural typology of intergenerational shared sites
}

\author{
Oxana Maslovsckaia ${ }^{1 *}[0000-0003-0315-4980]$, Alla Kopeva $^{1}{ }^{[0000-0002-1055-0909]}$, Mariia Matveieva $^{1}$

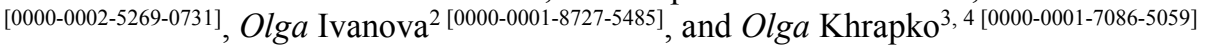 \\ ${ }^{1}$ Far Eastern Federal University, 690922, Ajax Bay, Russky Island, Vladivostok, Russia \\ ${ }^{2}$ Vladivostok State University of Economics and Service, 690014, Gogolya st., Vladivostok, Russia \\ ${ }^{3}$ Botanical Garden-Institute of Far Eastern Branch of Russian Academy of Sciences, 690024, \\ Makovskogo st., Vladivostok, Russia \\ ${ }^{4}$ Primorye State Academy of Agriculture, 692510, Blukher Avenue, Ussuriysk, Russia
}

\begin{abstract}
In the conditions of the modern world, there is an increasing socio-cultural gap between generations. To create sustainable development and functioning of society, to maintain its stability in the present and future, it is necessary to create conditions for strengthening intergenerational relations. All social programs must be accompanied by architectural programs, so there is a need for the architectural and urban planning transformation of the existing urban space in favor of the development of intergenerational ties. The purpose of this study is to determine the typological features of intergenerational centers based on a comparative analysis of existing facilities. Several different intergenerational shared sites examples around the world were analyzed. The analysis revealed a general typology of intergenerational environments: outdoor spaces for short-term intergenerational communication; indoor and outdoor spaces for intergenerational communication at centers; specialized housing estates and co-living buildings with public indoor and outdoor zones for intergenerational communication. The results of this work are the basis for further research, the purpose of which is to form the principles of an environment that promotes the development of intergenerational relations in Russian conditions and their approbation in the design of a residential area in Yakutsk.
\end{abstract}

Keywords: intergenerational shared sites, children, teenagers, youth and elderly people interaction.

\section{Introduction}

Architecture has always been a translator of social information, values of society. In the modern world there is aging of the population, age value asymmetry in society (emphasis on the development of children as builders of the future, and ignoring the needs of older people), rapid change and renewal of technologies and information, the decline in the quality of the modern institution of the family, as well as the lack of conditions for

\footnotetext{
*Corresponding author: oxym69@gmail.com
} 
intergenerational communications. There is an increasing socio-cultural gap between generations. This problem threatens the loss of national identity, national culture, spiritual and civilizational death. To create sustainable development and functioning of society, to maintain its stability in the present and future, it is necessary to create conditions for strengthening intergenerational relations [1]. All social programs must be accompanied by architectural programs, so there is a need for the architectural and urban planning transformation of the existing urban space in favor of the development of intergenerational ties.

The analysis of theoretical studies demonstrates that studies of the influence of the volumetric-spatial environment on interactions between generations are not as extensive as ones in other areas of science. Medicine, gerontology, geriatrics study the impact of interactions between different age groups on their well-being and health [2]. An economic assessment of the implementation of intergenerational programs is given in economic researches [3-5]. Sociologists determine the impact of intergenerational relations on society and social values $[6,7]$. It is important to approach the topic comprehensively, filling the gaps in scientifically based knowledge about the formation of an environment that develops intergenerational interactions for a complete understanding of the topic and the successful implementation of intergenerational programs [8].

In Russia, the study of the architectural and spatial environment that promotes social communication between generations has not yet been the subject of a special study, which makes it relevant to research the national characteristics of intergenerational shared sites.

The purpose of this study is to determine the typological features of intergenerational centers based on a comparative analysis of existing objects, as well as to suggest new types of intergenerational spaces.

The authors collected, summarized and analyzed sources containing information about theoretical positions and practical experience in creating the environment that develops intergenerational relationships. Basic information was obtained from domestic and foreign scientific journals, including those presented on the electronic library portal and the ScienceDirect interdisciplinary platform from Elsevier, as well as from monographic studies of scientists directly involved in the formation of an intergenerational communicative environment:

- implementation of an intergenerational program into the architectural and urban planning structure of the city $[9,10]$;

- prospects for the design of residential buildings for all age groups [11-13];

-influence of the spatial structure of buildings on interactions between older and younger generations [14];

- formation of intergenerational communication environment $[15,16]$; 19];

- formation of intergenerational communication environment in public open spaces [17-

- gardening as a space for intergenerational communication through learning [20, 21];

Along with them, works on the formation of a comfortable environment for certain age groups were studied:

- designing cities and public spaces for children [22-24];

- design of public spaces for the older group of generations [25-27].

Approaches to urban planning and building design from the point of view of comfort and accessibility for younger or older generations have a similar ideology with the creation of an intergenerational communicative environment. There is a number of studies to explain the differences and similarities between these approaches $[28,8]$.

In Russia, the existing social infrastructure does not meet the modern requirements. The typology of buildings presented in Russia cannot solve the problem of social segregation [29]. 


\section{Materials and methods}

At the stage of collecting and studying the source data, the following methods were used. At the stage of determining the degree of knowledge of the problem, a method was used to systematize theoretical sources: domestic and foreign scientific publications, including journals presented on the E-library portal and Elsevier's multidisciplinary ScienceDirect platform. At the stage of studying the practical experience of the functioning of intergenerational shared sites in different countries of the world, a comparative analysis of objects was carried out according to the following parameters: location in the city or in the suburbs, capacity (number of children and the elderly), site area and building area, functional zoning of the territory, functional content object, joint or separate nature of residence of different age groups, type of object: residential buildings, complexes and quarters; separate public buildings; open spaces of parks and squares).

\section{Results}

Six different intergenerational shared site examples around the world were analyzed:

Integrated intergenerational center Kotoen, Japan;

Intergenerational Learning Center at Providence Mount St. Vincent, Seattle, USA;

Intergenerational Nursery at Apples and Honey Nightingale, London, UK;

Intergenerational co-living Woonen Zorgcentrum Humanitas, Deventer, Netherlands;

Multigenerational community in Tampere, Finland;

Multigenerational park in Gainesville, Florida, USA.

Three of them are located in city centers, three - on the outskirts and suburbs. Capacities of buildings range from 250 people (100 children and 150 seniors) in downtown Kotoen in Japan to nearly 1,000 people ( 253 children and 700 seniors) the Gainesville park can accommodate. The structure of the building can be compact (Kotoen), however a branched system of spaces with semi-open courtyards (Providence Mount St. Vincent, Apples and Honey Nightingale, Woonen Zorgcentrum Humanitas) is more common, in Tampere it is a whole area of dispersed development. The building area is from $484 \mathrm{sq} . \mathrm{m}$ to 714 sq. $\mathrm{m}$ (excluding the Tampere area and the park in Florida) (Fig. 1).

Functional zones include: living quarters for the elderly, kindergartens, day care centers, training centers, communication areas in the form of recreation spaces, etc. The connection between these zones is very important; in intergenerational centers, representatives of a generation are given the opportunity to rest from each other's society, i.e. in such institutions, the connection between private and public areas is well balanced. Typically, the upper floors are occupied by living quarters, while common areas are concentrated on the ground floor. The exception is Apples and Honey Nightingale Intergenerational Center: the architects designed one common classroom on the top floor, which houses the living area; it uses a passive method of involving the older generation - older people on their way to their living rooms can stop to watch the children play through glass partitions, and also join them. The administrative and amenity zone is located away from all zones - either on the uppermost floors or in separate buildings.

The analysis revealed a general typology of intergenerational environments:

Model 1. This model assumes the separate living of generations, and it can both perform the function of dwelling for one generation, as well as not have such a function at all (Kotoen, Providence Mount St. Vincent, Apples and Honey Nightingale). Communication between generations takes place in the daytime, the main activity is joint leisure and education. It was revealed that at the moment nowhere is there a specially designed building with the function of uniting generations; such a model is presented only in already existing social and cultural-leisure institutions by adding such a function. 


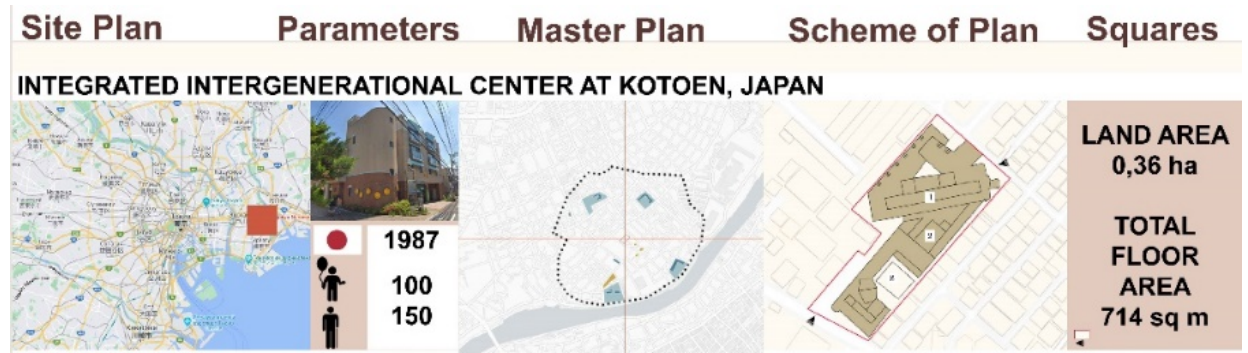

INTERGENERATIONAL LEARNING CENTER, PROVIDENCE MOUNT ST.VINCENT, SEATTLE, USA
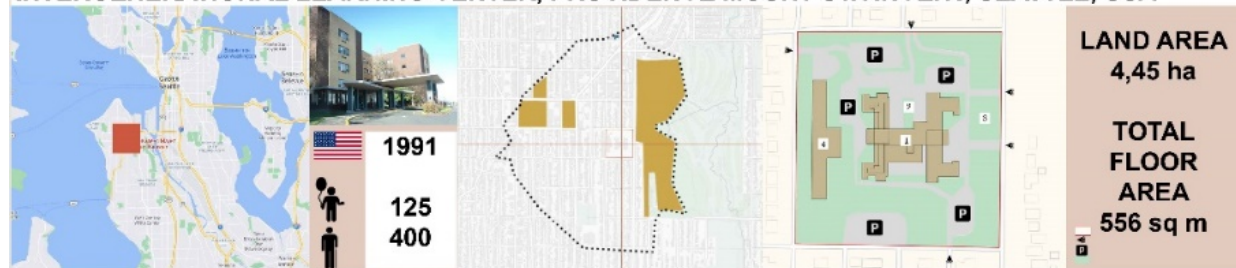

INTERGENERATIONAL NURSERY AT APPLES AND HONEY NIGHTINGALE, LONDON, UK
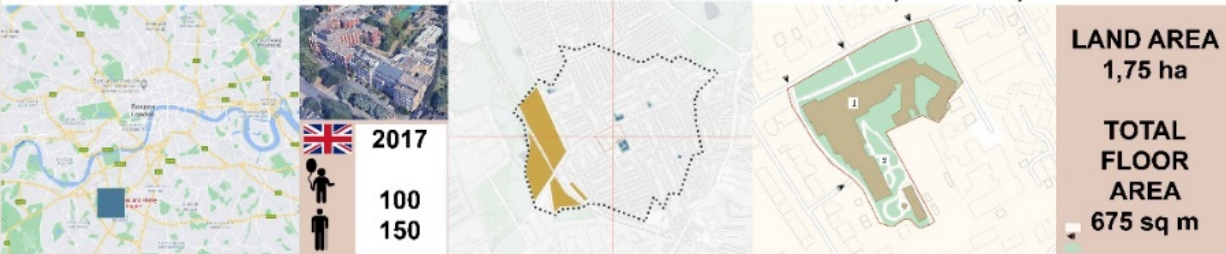

INTERGENERATIONAL CO-LIVING WOONEN ZORGCENTRUM HUMANITAS, DEVENTER, NETHERLANDS
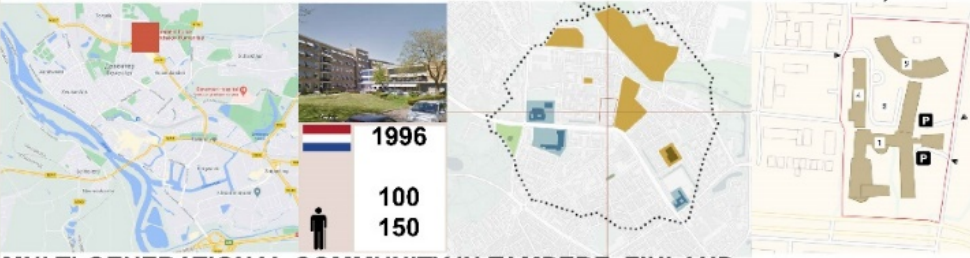

LAND AREA

1,87 ha

TOTAL

FLOOR

AREA

i:

MULTI-GENERATIONAL COMMUNITY IN TAMPERE, FINLAND

$484 \mathrm{sq} \mathrm{m}$
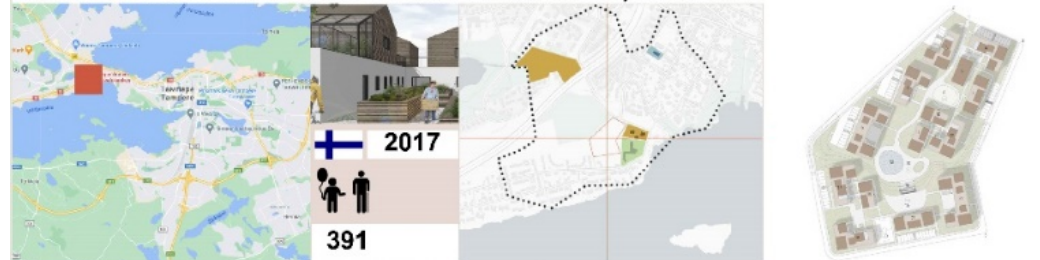

LAND AREA

1,80 ha

MULTIGENERATIONAL PARK IN GAINESVILLE, FLORIDA, USA

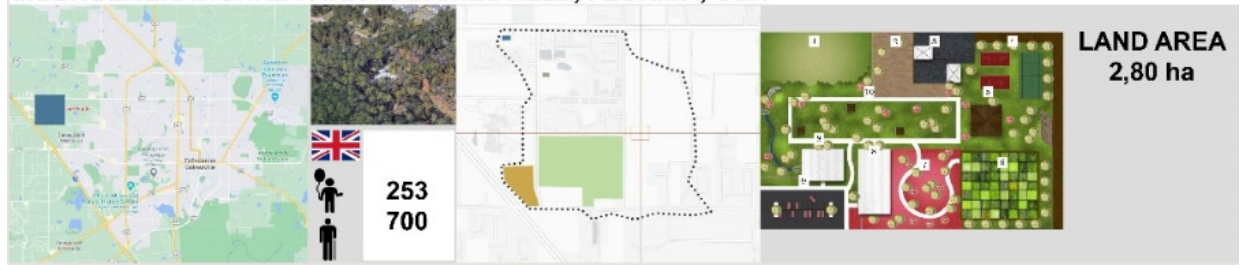

Fig. 1. General characteristic of analyzed intergenerational shared sites.

Model 2. Functionally, this model is assumed the joint constant dwelling and pastime of generations. This model can be implemented in social institutions, specialized housing estates and new coliving buildings (Woonen Zorgcentrum Humanitas, Multi-generational community in Tampere). In such a model, it is very important to competently approach the unification of generations, maintaining a balance between private and public zones. 
Model 3. This model does not imply long-term contact between generations. This can be open public and courtyard spaces (Generation Park in Florida). Contact between generations in these places is short-term, but regular. This model differs from the others it does not have special social programs that ensure the connection between generations. The contact of generations in such a model is based only on direct interest in each other, and therefore it is important to design such zones that can be equally used by both the younger and older generations (Fig. 2).

Views Functional Scheme

Model

INTEGRATED INTERGENERATIONAL CENTER AT KOTOEN, JAPAN
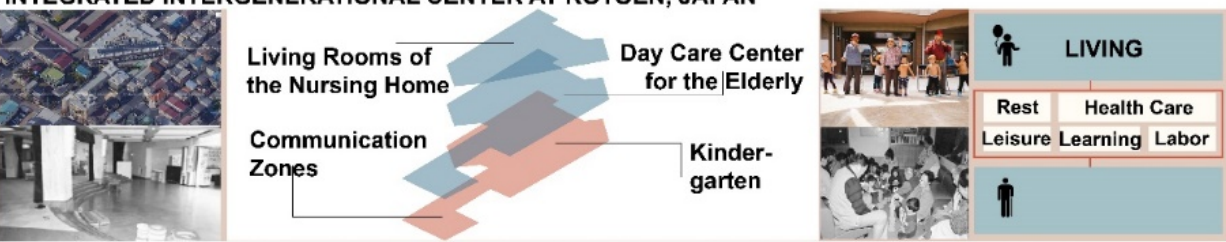

INTERGENERATIONAL LEARNING CENTER, PROVIDENCE MOUNT ST.VINCENT, SEATTLE, USA
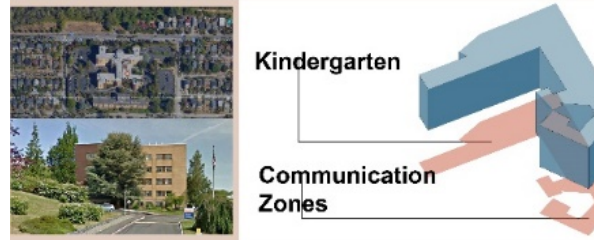

Living Rooms of the Nursing Home

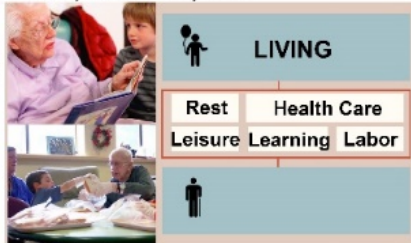

INTERGENERATIONAL NURSERY AT APPLES AND HONEY NIGHTINGALE, LONDON, UK
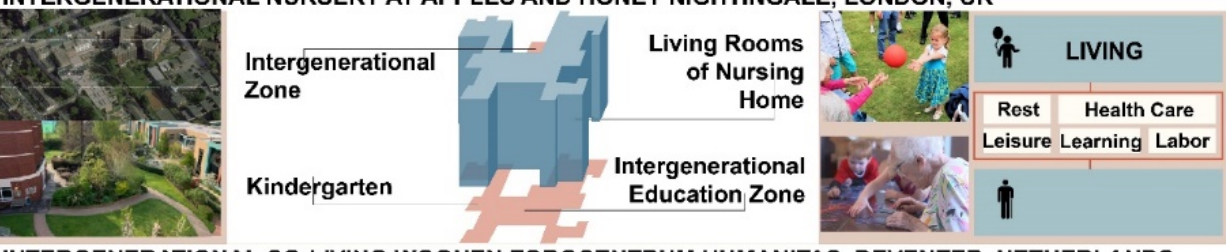

INTERGENERATIONAL CO-LIVING WOONEN ZORGCENTRUM HUMANITAS, DEVENTER, NETHERLANDS

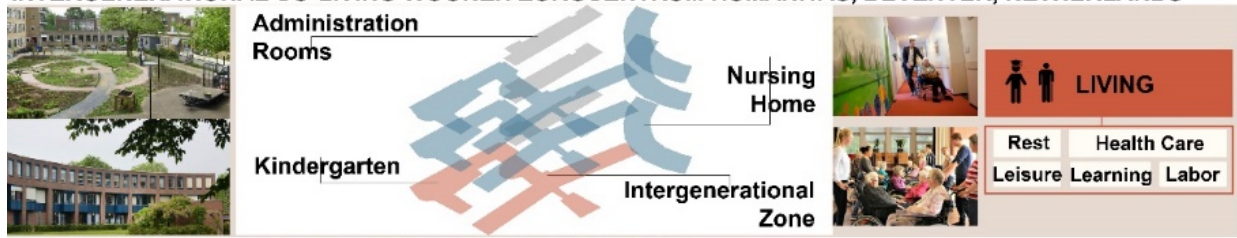

MULTI-GENERATIONAL COMMUNITY IN TAMPERE, FINLAND

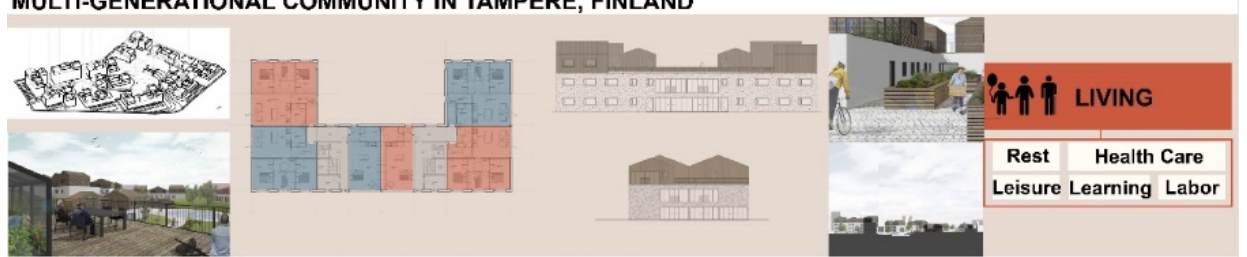

MULTIGENERATIONAL PARK IN GAINESVILLE, FLORIDA, USA

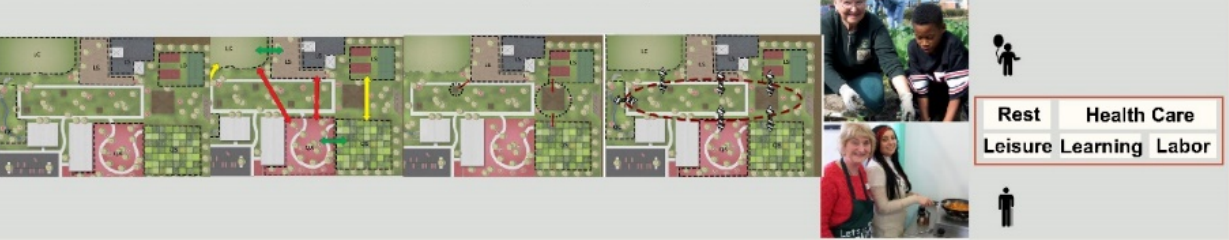

Fig. 2. Functional-spatial analysis of intergenerational shared sites. 


\section{Discussion}

Revealed typology of existing intergenerational environments has several functional-spatial models of possible intergenerational communication: the joint constant dwelling and pastime of generations; separate living of generations (or dwelling for one generation) with joint indoor and outdoor leisure and education; separate living of generations and shortterm outdoor contact between generations. However, this typology can be significantly expanded by a more comprehensive approach to the problem of intergenerational communication (Table 1).

Table 1. Formatting sections, subsections and subsubsections.

\begin{tabular}{|c|c|c|c|}
\hline \multirow{2}{*}{$\begin{array}{c}\text { Type of } \\
\text { Function }\end{array}$} & \multicolumn{3}{|c|}{ Structural level of the intergenerational environment } \\
\hline & City & District & Quarter \\
\hline $\begin{array}{c}\text { Open } \\
\text { public spaces }\end{array}$ & $\begin{array}{l}\text { Construction/ } \\
\text { reconstruction of open } \\
\text { public spaces (parks, } \\
\text { squares) of the city level }\end{array}$ & $\begin{array}{l}\text { Open public spaces } \\
\text { (parks, squares, } \\
\text { squares) of the district } \\
\text { level }\end{array}$ & $\begin{array}{l}\text { Construction/ } \\
\text { reconstruction of } \\
\text { residential courtyards } \\
\text { taking into account } \\
\text { the principles of the } \\
\text { intergenerational } \\
\text { environment }\end{array}$ \\
\hline $\begin{array}{l}\text { Cultural } \\
\text { and leisure } \\
\text { facilities }\end{array}$ & $\begin{array}{l}\text { Construction of new or } \\
\text { reconstruction of } \\
\text { existing cultural, } \\
\text { entertainment and } \\
\text { leisure facilities } \\
\text { (libraries, theaters, } \\
\text { exhibitions, } \\
\text { entertainment centers, } \\
\text { etc.) }\end{array}$ & $\begin{array}{l}\text { Construction of new or } \\
\text { reconstruction of } \\
\text { existing educational } \\
\text { institutions (combining } \\
\text { schools and } \\
\text { kindergartens with day } \\
\text { care centers for } \\
\text { pensioners, social } \\
\text { service centers) }\end{array}$ & $\begin{array}{l}\text { Construction of new } \\
\text { or reconstruction of } \\
\text { existing specialized } \\
\text { residential buildings } \\
\text { (association of } \\
\text { nursing homes and } \\
\text { hostels, hotels; } \\
\text { association of } \\
\text { nursing homes and } \\
\text { children's homes) }\end{array}$ \\
\hline $\begin{array}{l}\text { Housing } \\
\text { and social } \\
\text { institutions }\end{array}$ & $\begin{array}{l}\text { Construction of new or } \\
\text { reconstruction of } \\
\text { existing } \\
\text { intergenerational centers } \\
\text { - treatment and } \\
\text { prevention institutions } \\
\text { (sanatoriums, } \\
\text { rehabilitation centers, } \\
\text { hospitals, etc.) }\end{array}$ & $\begin{array}{l}\text { Construction of new } \\
\text { residential areas } \\
\text { according to the } \\
\text { principles of the } \\
\text { intergenerational } \\
\text { environment }\end{array}$ & $\begin{array}{l}\text { Construction of new } \\
\text { or reconstruction of } \\
\text { existing residential } \\
\text { buildings according } \\
\text { to the principles of } \\
\text { the intergenerational } \\
\text { environment, } \\
\text { including } \\
\text { extended family } \\
\text { apartments }\end{array}$ \\
\hline
\end{tabular}

\section{Conclusions}

Several different intergenerational shared site examples around the world were analyzed. The analysis revealed a general typology of intergenerational environments: the joint constant dwelling and pastime of generations; separate living of generations (or dwelling for one generation) with joint indoor and outdoor leisure and education; separate living of generations and short-term outdoor contact between generations. This typology can be significantly expanded by a more complex and comprehensive approach to the problem of intergenerational communication, including different types of multigenerational 
environments: open public spaces, cultural and leisure facilities, housing, and social institutions on the level of city, district, and quarter.

The results of this work are the basis for further research, the purpose of which is to form the principles of an environment that promotes the development of intergenerational relations in Russian conditions and their approbation in the design of a residential area in Yakutsk.

\section{References}

1. T. Buffel, F. De Backer, J. Peeters, C. Phillipson, V. Romero Reina, A. Kindekens, L. De Donder, K. Procedia Soc. Behav. Sci., 116, 1785-1791 (2014) DOI: 10.1016/j.sbspro.2014.01.472

2. S. Zhong, C. Lee, M.J. Foster, J. Bian. Soc. Sci., Med. 264, 113374 (2020) DOI: 10.1016/j.socscimed.2020.113374

3. N. Vecchio, T. Comans, P. Harris, V. Graham, A. Cully, N. Harris, J. Fitzgerald, J. Cartmel, X. Golenko, K. Radford, J. Intergener. Relatsh., 9, 1-20 (2020) DOI: 10.1080/15350770.2020.1810194

4. L. Nanu, F. Ali, K. Berezina, C. Cobanoglu, Int. J. Hosp. Manag., 89, 102530 (2020) DOI: 10.1016/j.ijhm.2020.102530

5. S. Upadhyaya, C.P. Blocker, H.R. Houston, M.R. Sims. J. Bus. Res. 125, 324-335 (2021) DOI: 10.1016/j.jbusres.2020.12.019

6. C. Giraudeau, N. Bailly, Eur. J. Ageing, 16, 363-376 (2019) DOI: 10.1007/s10433-018-00497-4

7. R. Peters et al. Arch. Gerontol. Geriatr., 94, 104356 (2021) DOI: 10.1016/j.archger.2021.104356

8. M. Kaplan, J. Haider, U. Cohen, D. Turner, J. Intergener. Relatsh., 5, 81-110 (2007) DOI: 10.1300/J194v05n02 06

9. S. García, P. Martí. ARQ, 86, 62-69 (2014) DOI: 10.4067/S0717-69962014000100009

10. L. G. Lebedeva, L. V. Orlova, IOP Conf. Series: Materials Science and Engineering 603, 042062 (2019) DOI: $10.1088 / 1757-899 \mathrm{x} / 603 / 4 / 042062$

11. T. E. Epimakhova, Designing for Multigenerational Community: Creating a Supportive Environment for Young and Old in the U.S.A., in Proceedings of the Clemson University, Clemson, U.S.A., 128 (2016) URL: https://core.ac.uk/download/pdf/268647129.pdf (last accessed: 25.03.2021)

12. E. Galand, A Multi-generational community, in Proceedings of the Tampere University of Technology, Tampere, Finland, 56 (2017) URL: https://trepo.tuni.fi/handle/123456789/25113

13. D. J. Miller, Intergenerational Housing: vernacular perspective, in Proceedings of the Pennsylvania State University, University Park, Pennsylvania, U.S.A., 133 (2014) URL: https://etda.libraries.psu.edu/catalog/21811 (last accessed: 25.03.2021)

14. M. Seo, Therapeutic and Developmental Design: The Relationship Between Spatial Enclosure and Impaired Elder-Child Social Interaction, in Proceedings of the Texas A\&M University, Texas A\&M University, College Station, Texas, U.S.A., 331 (2006) URL: https://oaktrust.library.tamu.edu/handle/1969.1/ETD-TAMU-1730

15. N. Norouzi, S. Jarrott, H. Chaudhury. J. Archit. Plann. Res., 36, 35-51 (2019) URL: $\mathrm{https}: / /$ www.scopus.com/record/display.uri?eid=2-s2.0-85084819264\&origin=resultslist\&zone=contextBox

16. S. E. Jarrott, A. J. Stremmel, J. J. Naar. J. Intergener. Relatsh., 17, 488-504 (2019) DOI: $10.1080 / 15350770.2019 .1579154$

17. R. Vanderbeck, N. Worth, Intergenerational Space, in Proceedings of the Routledge, London, England 342 (2015) DOI: $10.4324 / 9780203736920$

18. C.-R. Delgado-Acosta, C.-G. Calero-Martín, H. González-Bencomo. Documents d'Analisi Geografica, 62, 5-25 (2016) DOI: 10.5565/rev/dag.253

19. S. Reyes, Intergenerational Interactions: Designing for the Young \& Old, in Proceedings of the University of Florida, Gainesville, Florida, U.S.A., 147 (2016) URL: https://ufdc.ufl.edu/IR00007999/00001 (last accessed: 25.03.2021)

20. B. J. Hake. J. Intergener, Relatsh, 15, 26-38 (2017) DOI: 10.1080/15350770.2017.1260369

21. M .L. Predny, D. Relf. Hort Technology, 10, 64-70 (2000) DOI: 10.21273/HORTTECH.10.1.64

22. M. Li, J. Li, Procedia Engineering, 198, 790-801 (2017) DOI: 10.1016/j.proeng.2017.07.130

23. A. Özdemir, Cities, 93, 206-214 (2019) DOI: 10.1016/j.cities.2019.05.005 
24. X. Wang, H. Woolley, Y. Tang, H. Liu, Y. Luo, Cities, 72, 173-180 (2018) DOI: 10.1016/j.cities.2017.08.011

25. M. Afifi, B. Parke, M. Al-Hussein, Autom. Constr., 39, 117-125 (2014) DOI: 10.1016/j.autcon.2013.07.001

26. X. Ma, Y. Tian, M. Du, B. Hong, B. Lin, Sci. Total Environ, 768, 1-13 (2021) DOI: 10.1016/j.scitotenv.2021.144985

27. S. Song, D. Wang, W. Zhu, C. Wang, Technol. Forecast. Soc. Change, 152, 119859 (2020) DOI: 10.1016/j.techfore.2019.119859

28. P. Brownell, R., P. Resnick, J. Intergener, Relatsh, 3, 67-75 (2005) DOI: 10.1300/J194v03n01_06

29. A. Androsov, A. Kopeva, O. Maslovskai, The New Ideas of New Century: 17th Int. Sci. Conf. Proc. 2, 12-17 (2017) URL: https://www.elibrary.ru/item.asp?id=28995707 (last accessed: 25.03.2021) 